\title{
Perfil epidemiológico de infectados pelo vírus HIV com dermatoses em Natal/RN*
}

\section{Epidemiologic profile of HIV - positive patients with dermatoses in Natal/RN /Brazil}

Fernando Cardoso ${ }^{1}$

Heloísa Ramos ${ }^{2}$

Márcio Lobo

\begin{abstract}
Resumo: FundAMENTOS - Não há registro de dermatoses em infectados pelo vírus HIV no Rio Grande do Norte, embora haja 899 casos acumulados de AIDS em adultos entre janeiro de 1983 e agosto de 2000 e coeficientes de mortalidade por cem mil habitantes de 3,80 e 2,47, nos anos de 1995 e 1997, respectivamente, coincidindo essa diferença de valores, com o uso de antiretrovirais.

OBJEtivos - Descrever as características epidemiológicas de infectados, a freqüência de dermatoses e suas gravidades em usuários e não usuários de antiretrovirais.

MaterIAL E MÉTOdOS - Foram incluídos 172 pacientes conforme a classificação do CDC/1992; descrevendo-se 0 uso de antiretrovirais e dermatoses neles presentes.

RESULTADOS - A amostra teve $83,72 \%$ de homens, com média de idade de 37,17 anos, contaminados por via sexual (96,5\%), heterossexuais predominantes $(54,7 \%)$. As doenças cutâneas mais freqüentes foram as virais, fúngicas e miscelânia. 0 percentual médio da pele atingida pelas dermatoses foi 12,5\%. A média da carga viral foi $109.114,05 \mathrm{cps} / \mathrm{ml}$, e a de linfócitos $\mathrm{TCD}_{4}+$ foi $383,15 \mathrm{cél} / \mathrm{s} / \mathrm{mm}^{3}$, estando $81,4 \%$ destes, em uso de antiretrovirais.

CONCLUSÕES - 0 perfil epidemiológico dos infectados pelo vírus HIV no RN não difere das outras regiões brasileiras. Estudos analíticos que minimizem bias de confusão são necessários para aferir o grau de interferência do uso de antiretrovirais nesses indivíduos. Palavras-chave: dermatopatias; epidemiologia; síndrome de imunodeficiência adquirida.
\end{abstract}

Summary: BACKGROUND: There is no description of dermatoses among HIV infected individuals in Rio Grande do Norte(RN) / Brazil, althoug this state had an accumulated total of 899 adult Aids cases registered from january 1983 to august 2000 and mortality coefficients per 100,000 residents of 3.80 and 2.47, in the years 1995 and 1997, respectively, such that this difference in values coincided with the introduction of antiretroviral (ARV) usage in this state.

OBJECTIVE: To describe epidemiologic caracteristics of retrovirus infected subjects with dermatoses, including frequency of dermatoses and to establish relationships between the caracteristics of users and nonusers of ARV drugs.

MaterIaL and Methods: Were included 172 patients, according to HIV infection classification of CDC/1992. The use of ARV drugs was determined and the dermatoses were submited to analysis.

RESULTS: The sample comprises $83.72 \%$ of men, with mean age of 37.17 years, with sexual way of retrovirus contamination (96.5\%), predominant heterossexual behaviour (54.7\%). The most frequent form skin diseases were classified into viral, fungic and miscellaneous. The mean percentage of diseased skin area was $12.5 \%$. Mean viral load was $109,114.05 \mathrm{cps} / \mathrm{ml}$, and mean $\mathrm{CD}_{4}+\mathrm{T}$ lymphocytes was 383.15 cells $/ \mathrm{mm}^{3}$. Overal $81.4 \%$ of patients were using ARV drugs.

ConcLusions: The epidemiologic profile of HIV infected patients residents in state of RN did not differ from that of others brazilian regions. Analytic studies, minimizing confounding bias, are necessary to discribe the real frequency of HAART (High Active Antiretroviral Therapy) in seropositive HIV subjects.

Key words: skin diseases; epidemiology; acquired immunodeficiency syndrome.

Recebido em 20.09.2001. / Received in September, $20^{\text {th }}$ of 2001.

Aprovado pelo Conselho Consultivo e aceito para publicação em 05.11.2002. / Approved by the Consultive Council and accepted for publication in November, 05 ${ }^{\text {th }}$ of 2002. * Trabalho realizado no Hospital Giselda Trigueiro-Natal/RN / Work done at the "Hospital Giselda Trigueiro - Natal/RN".

Mestre, Universidade Federal de Pernambuco. Dermatologista, Universidade de São Paulo-Ribeirão Preto. Preceptor de ensino, dermatologia sanitária, Hospital de infectologia Giselda Trigueiro, Natal/RN. / Master Degree, "Universidade Federal de Pernambuco". Dermatologist, "Universidade de São Paulo-Ribeirão Preto". Head of Teaching Dept., Sanitary Dermatology, "Hospital de Infectologia Giselda Trigueiro", Natal/Rio Grande do Norte State.

${ }^{2}$ Mestre, Universidade de São Paulo. Doutora, Universidade de São Paulo. Professora-adjunto, Universidade Federal de Pernambuco. Chefia, enfermaria de clínica médica do Hospital das Clínicas. / Master Degree, "Universidade de São Paulo". PhD, "Universidade de São Paulo". Adjunct-Professor, "Universidade Federal de Pernambuco". Head of the Infirmary of the Medical Clinic at the "Hospital das Clínicas".

${ }^{3}$ Livre-docente, Universidade Federal de Pernambuco. Professor titular, dermatologia, Departamento de Medicina Tropical da Universidade Federal de Pernambuco. Coordenador da Pósgraduação em Medicina Tropical da Universidade Federal de Pernambuco / Lecturer, "Universidade Federal de Pernambuco". Titular Professor of Dermatology, Tropical Medicine Department of the "Universidade Federal de Pernambuco". Coordinator of Post-graduate Studies in Tropical Medicine at the "Universidade Federal de Pernambuco".

(C)2003 by Anais Brasileiros de Dermatologia 


\section{INTRODUÇÃO}

Segundo dados da Coordenação Nacional de Doenças Sexualmente Transmissíveis e Aids do Ministério da Saúde, desde o início da epidemia até 03/06/2000, 190.949 casos de Aids foram notificados no Brasil. A maioria concentra-se na região Sudeste com coeficiente de incidência acumulado até 03/06/2000 de 210; as demais regiões apresentam estes coeficientes: Sul (131); CentroOeste $(102,1)$; Nordeste $(40,9)$ e Norte $(36,4)$.

O número de casos de Aids em adultos no Rio Grande do Norte, notificados no Sistema de Informações de Agravos de Notificação - Sinan, da Secretaria Estadual de Saúde do Rio Grande do Norte, no período de janeiro de 1983 a 26 de agosto de 2000, é de 899, sendo 675 do sexo masculino, e 800 na faixa etária entre 20 e 49 anos.

Natal e Mossoró, centros de referência para doenças infecciosas no estado, contribuíram com 596 e 59 registros respectivamente.

Com relação às doenças associadas à retrovirose, observa-se grande frequiência de dermatoses, abrangendo etiologias infecciosas e parasitárias; neoplásicas; e inflamatórias, auto-imunes ou de etiologia multifatorial. ${ }^{1-8}$

A contagem de linfócitos $\mathrm{T}$ Helper $\mathrm{CD}_{4}+$, no sangue periférico, é um marcador laboratorial da progressão de imunodeficiência induzida pelo vírus HIV, e o número de cópias de RNA viral é um preditor da progressão da imunodeficiência, independente das contagens de linfócitos $\mathrm{T} \mathrm{CD}_{4}+{ }^{7-16}$

A utilização de "medicamentos antiretrovirais altamente eficazes" (ou High Active Antiretroviral Therapy HAART) desde 1995 desencadeou mudanças na apresentação e evolução das dermatoses em infectados pelo retrovírus, podendo promover o desaparecimento de lesões cutâneas ou prevenir doenças oportunistas mais graves, resultado da recuperação parcial do sistema imunológico. ${ }^{17}$

O Hospital Giselda Trigueiro, em Natal/RN, referência de doenças infectocontagiosas para a capital, registrou $66,3 \%$ das notificações de Aids do estado no período de janeiro de 1983 a agosto de 2000, sendo o local do estudo aqui relatado.

Este trabalho permite documentar as características epidemiológicas e imunitárias de amostra de infectados pelo vírus HIV, a frequiência de dermatoses e suas relações com: o percentual de superfície corpórea atingida, a conta-

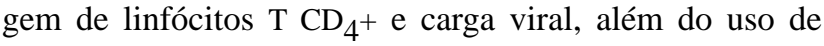
medicamentos antiretrovirais.

\section{CASUÍSTICA E MÉTODOS}

O estudo foi aprovado pela Comissão de Ética Médica do Hospital Giselda Trigueiro em Natal/RN. Obteve-se consentimento, por escrito, dos participantes.

Foram avaliados, quanto à presença de dermatoses, 381 pacientes com idade superior a 13 anos, infectados pelo vírus HIV, abordados por ocasião da procura do ambulatório especializado em Aids e internados, por motivos operacionais, apenas nos cinco primeiros leitos pares da

\section{INTRODUCTION}

According to data from the National Coordination of Sexually Transmissible Diseases and Aids of the Ministry of Health, since the beginning of the epidemic up until 06/03/2000, 190,949 cases of Aids have been notified in Brazil. Most cases are concentrated in the Southeast area with an accumulated incidence coefficient of 210 up to June 03, 2000; the remaining areas present the following coefficients: South (131); Central-west (102.1); Northeast (40.9) and North (36.4).

The number of cases of Aids in adults in Rio Grande do Norte, presented in the Notification System (Sinan) of the State General Office of Health of Rio Grande do Norte, from January 1983 to August 26, 2000 was 899, of which 675 were male and 800 in the 20 to 49-year-old age group.

Natal and Mossoró, reference centers for infectious diseases in the state, contributed with 596 and 59 notifications, respectively.

Regarding the diseases associated to retrovirus, a great frequency of dermatoses were observed with etiologies including infectious and parasitic; neoplastic; and inflammatory, auto-immune or multifactorial. ${ }^{1-8}$

The $\mathrm{CD}_{4}+$ helper cells count in the peripheral blood is a laboratorial marker of the progression of immunodeficiency induced by HIV, and the number of copies of viral RNA is a predictor of the degree of immunodeficiency, irrespective of the $\mathrm{CD}_{4}+\mathrm{T}$ lymphocyte counts. ${ }^{7,14-16}$

The use of highly effective antiretroviral medicines (or Highly Active Antiretroviral Therapy - HAART) since 1995, has triggered changes in the presentation and course of the dermatoses in those infected by a retrovirus and can promote the disappearance of cutaneous lesions and prevent more serious opportunist diseases, following a partial recovery of the immunological system. ${ }^{17}$

The present study was performed at the Hospital Giselda Trigueiro, in Natal/RN, a reference center for infectious and contagious diseases in the capital and that registered $66.3 \%$ of the Aids notifications in the state from January 1983 to August 2000.

This work enabled a documentation of the epidemic and immunological characteristics of a sample infected by $H I V$, the frequency of dermatoses and their relationship in terms of: the percentage of body surface involved, the $\mathrm{CD}_{4}+$ $T$ lymphocyte count and viral load, as well as the use of antiretroviral medicines.

\section{PATIENTS AND METHODS}

The Commission of Medical Ethics of the Hospital Giselda Trigueiro (HGT) in Natal/RN approved the study. Informed and written consent was obtained from all participants.

A total of 381 patients over 13 years of age and infected by HIV were evaluated according to the presence of dermatoses. The patients were interviewed when they sought a specialized Aids clinic and were hospitalized, for 
enfermaria de Aids no período de 01 de setembro de 1999 a 29 de fevereiro de 2000.

Foram incluídos no estudo 172 pacientes, sendo 159 em ambulatório, e 13, em regime de internação hospitalar. O total de indivíduos com dermatoses foi 209, correspondendo a 45,14\% dos 381 pacientes entrevistados infectados pelo retrovírus.

De cada paciente registrou-se o número total de dermatoses presentes ao exame físico, com posterior tentativa de confirmação laboratorial. As dermatoses tiveram um único momento de registro, época da primeira avaliação dermatológica.

Para as dermatoses classificadas clinicamente como de provável etiologia bacteriana, fizeram-se culturas para germes comuns, mediante coleta de exsudato ou descamação epitelial, se presentes.

Para as de provável etiologia fúngica, fizeram-se exames micológicos diretos e cultura para fungos, caso possuíssem descamação epitelial suficiente para coleta; exceção feita à dermatose de acometimento sistêmico histoplasmose, caso em que houve necessidade de efetuar biópsia cutânea e estudo anatomopatológico. Para as zoodermatoses fizeram-se exames microscópicos diretos, com pesquisa do provável agente, caso houvesse material suficiente para a confirmação laboratorial.

Para todas as dermatoses neoplásicas fizeram-se biópsias com punch número seis e estudo anatomopatológico.

Para as descamantes, incluídas na classificação clínica de dermatoses não infecciosas, não parasitárias e não neoplásicas (miscelânea) fizeram-se exames microscópicos diretos com pesquisa de agentes etiológicos, na tentativa de diferenciá-las de dermatoses de outras etiologias ou detectar associações parasitárias ou infecciosas; efetuando-se biópsias cutâneo-mucosas e estudo anatomopatológico no caso de dúvida diagnóstica.

Para as lesões de acometimento oral, anal ou genital não se fizeram exames complementares invasivos por dificuldades técnicas inerentes ao serviço.

Foram incluídos todos os pacientes com dermatoses, infectados pelo vírus HIV (apresentando duas sorologias anti-HIV positivas pelo método Elisa de terceira geração e uma sorologia positiva confirmatória, imunofluorescência indireta ou Western-Blot), sintomáticos ou não, que apresentavam exames laboratoriais como contagem de linfócitos $\mathrm{T}$ $\mathrm{CD}_{4}+$ e carga viral documentadas, com até quatro meses de intervalo entre a coleta e a data do exame dermatológico.

As dermatoses foram diagnosticadas clinicamente e classificadas clinicolaboratorialmente em sete itens, segundo Zalla et al. ${ }^{18}$ e Ray \& Gateley, ${ }^{19}$ quais sejam: 1) infecções bacterianas; 2) infecções virais; 3) infecções fúngicas; 4) infestações por artrópodes; 5) infestações por protozoários; 6) neoplasias cutâneas e 7) dermatoses não infecciosas, não parasitárias e não neoplásicas ou de etiologia mal definida (miscelânea).

Sua gravidade foi avaliada conforme a extensão de acometimento corpóreo (regra dos nove, para cálculo de operational reasons, in the first five equal-numbered beds of the Aids infirmary during the period from September 01, 1999 to February 29, 2000.

Overall, 172 patients were included in the study, of which 159 were attended at the clinic and 13 were hospitalized. A total of 209 individuals presented dermatoses, corresponding to $45.14 \%$ of the 381 patients interviewed infected by the retrovirus.

For each patient, the total number of dermatoses present at physical exam was recorded with a subsequent attempt at laboratorial confirmation. The dermatoses were all registered at the time of the first dermatological evaluation.

For the dermatoses classified clinically as having a probable bacterial etiology, cultures for common germs were performed through collection of the exudate or epithelial desquamation when present.

For those of probable fungal etiology, direct mycological exams and culture for fungi were undertaken, whenever there was insufficient epithelial desquamation for collection; except for the cases when the dermatosis involved systemic histoplasmosis, which made it necessary to perform a cutaneous biopsy and anatomicopathological study. For the zoodermatoses, direct microscopic exams were done with tests for the probable agent whenever there was sufficient material for laboratorial confirmation.

Biopsies were performed for all of the neoplastic dermatoses using a number six punch and anatomicopathological study.

For the desquamative diseases included in the clinical classification of noninfectious, non-parasitic and non-neoplastic (miscellaneous) dermatoses, direct microscopic exams with tests for etiological agents were performed in an attempt to differentiate these from dermatoses of other etiologies or to detect parasitic or infectious associations; biopsies of cutaneous-mucous membranes and anatomicopathological study were done in the case of a doubtful diagnostic.

For lesions with oral, anal or genital involvement, complementary invasive exams were not undertaken due to technical difficulties inherent to the service.

All the HIV positive patients (presenting two antiHIV positive serological tests by the third-generation Elisa method and one positive confirmatory serology through indirect immunofluorescence or Western-Blot) and those presenting dermatoses, whether they were symptomatic or not, with laboratory exams such as $\mathrm{CD}_{4}+\mathrm{T}$ lymphocytes count and documented viral load with up to a four-month interval between the collection and the date of the dermatological exam were included.

The dermatoses were diagnosed clinically and classified by clinical and or laboratory methods into seven items, according to Zalla et al. ${ }^{18}$ and Ray \& Gateley, ${ }^{19}$ as follows: 1) bacterial infections; 2) viral infections; 3) fungal infections; 4) infestations by arthropods; 5) infestations by protozoa; 6) cutaneous neoplasias; and 7) noninfectious, non-parasitic and non-neoplastic dermatoses or those with 
percentagem da superfície corporal queimada): segmento cefálico e pescoço, $9 \%$; membros superiores, $9 \%$ cada segmento; hemitroncos e membros inferiores, $18 \%$ cada segmento. ${ }^{20}$

No momento da primeira consulta dermatológica, os pacientes foram separados, segundo a classificação de infecção pelo HIV do CDC/1992, em indivíduos sem imunossupressão acentuada (os enquadrados nas categorias A1, A2, B1, B2, daquela classificação) e indivíduos com imunossupressão acentuada (aqueles que se enquadraram nas categorias A3, B3, C1, C2, C3 da mesma classificação, como resume o quadro 1 .

A contagem de linfócitos do sangue periférico dos pacientes foi realizada pelo aparelho Facscount, técnica de citometria de fluxo. ${ }^{21}$

A técnica, utilizada para quantificação de RNA viral, foi a Nuclisens, licenciada pela Organon Teknika, Inc., mediante o uso do aparelho de quantificação computadorizado Nuclisens reader, sendo o limite de detecção de $80 \mathrm{cps} / \mathrm{ml}$.

Os resultados foram submetidos a análise estatística. Para comparação de dados, foram utilizados os testes T-student, F de Fisher e Snedecor (Anova), teste de Duncan e Qui-quadrado. O nível de significância mínimo adotado foi de $5 \%$.

\section{RESULTADOS}

Os motivos da procura do serviço de referência em Aids para primeira consulta ou para efetuar sorologia anti-HIV foram: 1) encaminhamento médico ou paramédico (39\% dos casos); 2) parceiro soropositivo ou com Aids $(22,1 \%)$; 3) queixas clínicas ou doenças que alertaram o indivíduo para a possibilidade de estar infectado (16,9\%); 4) outros motivos, não listados no protocolo $(9,3 \%)$; 5) encaminhamento do banco de sangue $(8,1 \%) ; 6)$ sugestão de amigo soropositivo ou receio de contaminação (por ter tido relação sexual desprotegida) ou de doença sexualmente transmissível $(4,7 \%)$.

Foram registradas 358 dermatoses, classificadas em 36 diagnósticos clínicos, conforme tabelas 1 e 2 . Não houve registro de dermatoses por protozoários. Os percentuais de ocorrên- a poorly defined etiology (miscellaneous).

The severity was evaluated according to the extension of corporal involvement (using the rule of nines for calculating body surface area involved in burns): cephalic segment and neck, 9\%; superior members, 9\% each segment; hemithorax and lower members, $18 \%$ each segment. ${ }^{20}$

The patients were divided into groups after their first dermatological consultation according to the HIV infection classification in the CDC/1992. The groups were formed by individuals without marked immunosuppression (divided into categories A1, A2, B1, B2, of this classification) and individuals with marked immunosuppression (these were placed in the categories $A 3, B 3, C 1, C 2, C 3$ of the same classification, as summarized in box 1).

The lymphocyte count of the peripheral blood was performed with Facscount equipment using flow cytometry technique. ${ }^{21}$

The method used for quantification of viral RNA, was Nuclisens, licensed by Organon Teknika, Inc., with a computerized quantification Nuclisens reader and detection limit of $80 \mathrm{cps} / \mathrm{ml}$.

The results were submitted to statistical analysis. A comparison of the data was established with Student's T test, Fisher and Snedecor F test (Anova), Duncan's test and Chisquare. The 5\% minimum significance level was adopted.

\section{RESULTS}

The motives for seeking medical help in the first consultation at the Aids reference service or to undergo anti-HIV serology were: 1) medical or paramedical referral (39\% of cases); 2) partner seropositive or with Aids (22.1\%); 3) clinical complaints or diseases that alerted the individual regarding the possibility of being infected (16.9\%); 4) other reasons, not stipulated in the protocol (9.3\%); 5) referral by a blood bank (8.1\%); 6) suggestion by a seropositive friend or fear of contamination (after sexual relationship without protection) with a sexually transmissible disease $(4.7 \%)$.

All the 358 dermatoses were registered and classified into 36 clinical diagnoses, as summarized in tables 1 and 2. There was no record of dermatosis caused by protozoa. The

Quadro 1: Classificação da Infecção pelo HIV - CDC/1992 / Box 1: Classification of the HIV Infection - CDC/1992

Categorias clínicas / Categorias clínicas$$
\text { A }
$$

Categorias laboratoriais (linfócitos T CD4+)

Laboratory categories

(CD4+ T lymphocytes)

(1) $>500 / \mathrm{mm}^{3}$

(2) $200 \mathrm{a} 499 / \mathrm{mm}^{3}$

(3) $<200 / \mathrm{mm}^{3}$
Assintomático, linfadenopatia generalizada persistente ou infecção aguda / Asymptomatic, generalized persistent adenopathy or acute infection

A1

A2

A3
Sintomático não $\mathrm{A}$, não $\mathrm{C}$

Symptomatic, not A or C
Condições indicativas de Aids / Features indicative of Aids

Fonte: Rachid M, Schechter M (1999). / Source: Rachid M, Schechter M (1999). 
Tabela 1: Médias de linfócitos $\mathrm{T} \mathrm{CD}_{4}+\left(\right.$ céls $\left./ \mathrm{mm}^{3}\right)$, carga viral $(\mathrm{cps} / \mathrm{ml})$ e valores unitários para todas as dermatoses detectadas em 172 pacientes atendidos no HGT (Natal/RN) no período de setembro/1999 a fevereiro/2000 (ordem decrescente de freqüência das dermatoses).

Table 1: Mean values of the $\mathrm{CD}_{4}+\mathrm{T}$ Iymphocytes (cells/mm 3 ), viral load $(\mathrm{cps} / \mathrm{ml})$ and unitary values for all the dermatoses detected in 172 patients attended at the HGT (Natal/RN) from September 1999 to February 2000 (Frequency of dermatoses in decreasing order).

\begin{tabular}{|c|c|c|c|}
\hline \multirow{3}{*}{$\begin{array}{l}\text { Diagnóstico } \\
\text { dermatológico } \\
\text { Dermatological } \\
\text { Diagnosis } \\
\end{array}$} & \multirow{3}{*}{$\begin{array}{l}\text { Número } \\
\text { de casos } \\
\text { Number } \\
\text { of cases }\end{array}$} & \multicolumn{2}{|c|}{$\begin{array}{l}\text { Médias e valores únicos } \\
\text { Mean and single values }\end{array}$} \\
\hline & & LinfócitosT CD4+ & Carga viral \\
\hline & & CD4+ T Lymphocytes & Viral load \\
\hline Dermatofitose / Dermatophytosis & 94 & 371.5 & $159,198.2$ \\
\hline Dermatite seborréica / Seborrheic dermatitis & 67 & 358.2 & $122,942.4$ \\
\hline EPP do HIV / PPE of HIV & 37 & 276.3 & $193,922.6$ \\
\hline Verrugas vulgares / Common warts & 16 & 337.0 & $18,846.9$ \\
\hline Candidíase mucocutânea / Mucocutaneous candidiasis & 14 & 248.8 & $284,141.4$ \\
\hline Pitiríase versicolor / Versicolor pityriasis & 14 & 537.5 & $20,445.0$ \\
\hline Ictiose adquirida / Acquired ichthyosis & 13 & 283.4 & $21,777.7$ \\
\hline Herpes simples / Herpes simplex & 12 & 410.1 & $72,608.3$ \\
\hline Escabiose / Scabies & 12 & 539.5 & $221,353.1$ \\
\hline Condiloma acuminado / Condyloma acuminatum & 11 & 431.6 & $22,000.0$ \\
\hline Foliculite / Folliculitis & 9 & 503.9 & $38,765.3$ \\
\hline Furúnculo / Furuncle & 6 & 529.0 & $452,485.0$ \\
\hline Leucoplasia pilosa oral / Oral pilar leukoplasia & 6 & 377.3 & $299,530.0$ \\
\hline Molusco contagioso / Molluscum contagiosum & 6 & 277.0 & $124,666.7$ \\
\hline Hipercromia ungueal / Unguinal hyperchromia & 5 & 397.0 & $26,540.0$ \\
\hline Éctima / Ecthyma & 4 & 645.5 & $21,000.0$ \\
\hline Eczema inespecífico / Nonspecific eczema & 4 & 250.8 & $126,150.0$ \\
\hline Balanopostite bacteriana / Bacterial balanoposthitis & 3 & 380.7 & $3,636.7$ \\
\hline Herpes-zóster / Herpes zoster virus & 3 & 502.3 & $31,446.7$ \\
\hline Sarcoma de Kaposi / Kaposi's sarcoma & 3 & 277.7 & $63,333.3$ \\
\hline Carcinoma basocelular / Basal cell carcinoma & 2 & 176.5 & $21,000.0$ \\
\hline Psoríase / Psoriasis & 2 & 1061.5 & $5,000.0$ \\
\hline Queratose actínica / Actinic keratosis & 2 & 205.0 & 0.0 \\
\hline Xerodermia / Xeroderma & 2 & 70.5 & $12,500.0$ \\
\hline Eritrodermia / Erythroderma & 1 & 157.0 & $72,000.0$ \\
\hline Fotodermatite / Photodermatitis & 1 & 189.0 & $39,000.0$ \\
\hline Granuloma anular / Granuloma annulare & 1 & 45.0 & $850,000.0$ \\
\hline Histoplasmose disseminada / Disseminated histoplasmosis & 1 & 327.0 & $40,000.0$ \\
\hline Impetigo bolhoso / Impetigo bullosa & 1 & 386.0 & 140.0 \\
\hline LE cutâneo crônico / Chronic cutaneous $L E$ & 1 & 722.0 & 0.0 \\
\hline LE induzido por medicamento / Drug-induced $L E$ & 1 & 257.0 & $1,300.0$ \\
\hline Linfoma sem classificação histológica / Lymphoma without histological classification & 1 & 145.0 & 90.0 \\
\hline Papulose bowenóide / Papulose bowenóide & 1 & 16.0 & $9,600.0$ \\
\hline Sífilis / Sífilis & 1 & 838.0 & $39,000.0$ \\
\hline Vitiligo / Vitiligo & 1 & 225.0 & $120,000.0$ \\
\hline Total & 358 & 364.9 & $130,983.4$ \\
\hline
\end{tabular}

cia das dermatoses nos indivíduos com e sem imunossupressão acentuada estão no gráfico 1 .

Utilizando-se teste Qui-quadrado, não se observou diferença estatisticamente significante no número absoluto de dermatoses por diagnósticos afins entre os grupos com e sem imunossupressão acentuada ( $\mathrm{G} 2=6,35$ com quatro graus de liberdade e $\mathrm{p}=0,174$ ).

As dermatoses mais freqüentes foram classificadas em: miscelânea (dermatite seborréica, erupção papuloprurí- occurrence percentage of dermatoses in individuals with and without marked immunosuppression is shown in graphic 1.

The Chi-square tests did not reveal any statistically significant difference in the absolute number of dermatoses by similar diagnoses between the groups with and without marked immunosuppres$\operatorname{sion}(G 2=6.35$ with four degrees of freedom and $p=0.174)$.

The most frequent dermatoses were classified as: miscellaneous (seborrheic dermatitis, papular pruritic eruption of $H I V$, acquired ichthyosis, unguinal hyperchromia, nonspecific 
Gráfico 1: Percentual de ocorrência de dermatoses, por categoria, segundo o grau de imunossupressão de 172 pacientes atendidos no HGT (Natal/RN) no período de setembro/1999 a fevereiro/2000. / Graphic 1:

Occurrence in percentages of dermatoses per category, according to the degree of immunosuppression of 172 patients attended at the HGT Natal/RN) from September 1999 to February 2000.

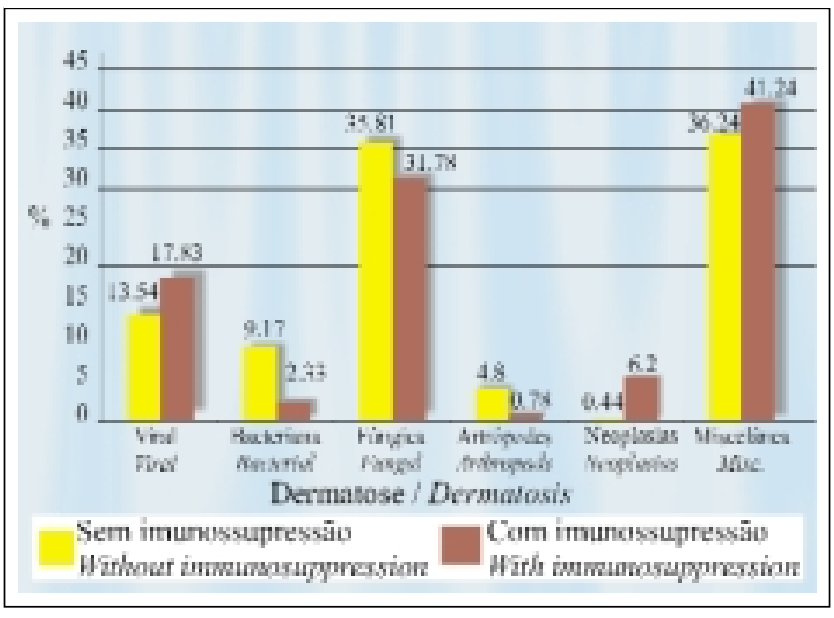

tica do HIV, ictiose adquirida, hipercromia ungueal, eczema inespecífico, psoríase, xerodermia, eritrodermia, dermatite de contato fotoalérgica, granuloma anular, lúpus eritematoso e vitiligo), fúngicas e virais, as quais representaram $38 \%$, $34,4 \%$ e $15,1 \%$ da amostra, respectivamente.

Os oito diagnósticos mais freqüentes $(74,6 \%$ das dermatoses), foram: dermatofitoses, dermatite seborréica, Erupção papulosa prurítica (EPP do HIV), verruga vulgar, candidíase mucocutânea, pitiríase versicolor, ictiose adquirida e herpes simples.

Quarenta e dois pacientes apresentaram 49 lesões em mucosas à inspeção clínica $(28,4 \%$ da amostra), sendo 20 lesões orais (11 casos de candidíase, seis de leucoplasia pilosa oral, um de herpes simples, um de herpes-zóster e um de linfoma sem classificação histológica), três anais (dois casos de condiloma acuminado e um caso de herpes simples) e 26 genitais (oito casos de condiloma acuminado, sete casos de herpes simples, quatro de molusco contagioso, três de balanopostite bacteriana, dois casos de balanopostite candidiásica, um de papulose bowenóide, um de vitiligo).

As freqüências de dermatoses, assim como as contagens de linfócitos $\mathrm{T} \mathrm{CD}_{4}+$ e cargas virais para cada respectivo diagnóstico, foram registradas na tabela 1 .

A representação gráfica da extensão percentual de pele acometida por dermatoses nos pacientes com e sem imunossupressão acentuada encontra-se no gráfico 2 .

A média de linfócitos $\mathrm{T}_{\mathrm{CD}_{4}}+$, em números absolutos (céls $/ \mathrm{mm}^{3}$ ) foi de 383,15 , e de linfócitos $\mathrm{T} \mathrm{CD}_{8}+$ foi de $1.147,00$, sendo a média da relação $\mathrm{CD}_{4} / \mathrm{CD}_{8}=0,33$, e da carga viral de $109.114,05 \mathrm{cps} / \mathrm{ml}$.

Os valores de linfócitos $\mathrm{T} \mathrm{CD}_{4}+$ predominantes estavam acima de 200 células $/ \mathrm{mm}^{3}$ (73,8\% da amostra), Os
Gráfico 2: Percentual médio de superfície corpórea acometida por dermatoses em 172 pacientes avaliados no HGT(Natal/RN) no período de setembro/1999 a fevereiro/2000, segundo categoria de dermatoses e grau de imunosspressão dos indivíduos. / Graphic 2:

Mean percentage of body area involved by the dermatoses in 172 patients Evaluated at the HGT (Natal/RN) from September 1999 to February 2000, according to the classification of the dermatoses and degree of immunosuppression.

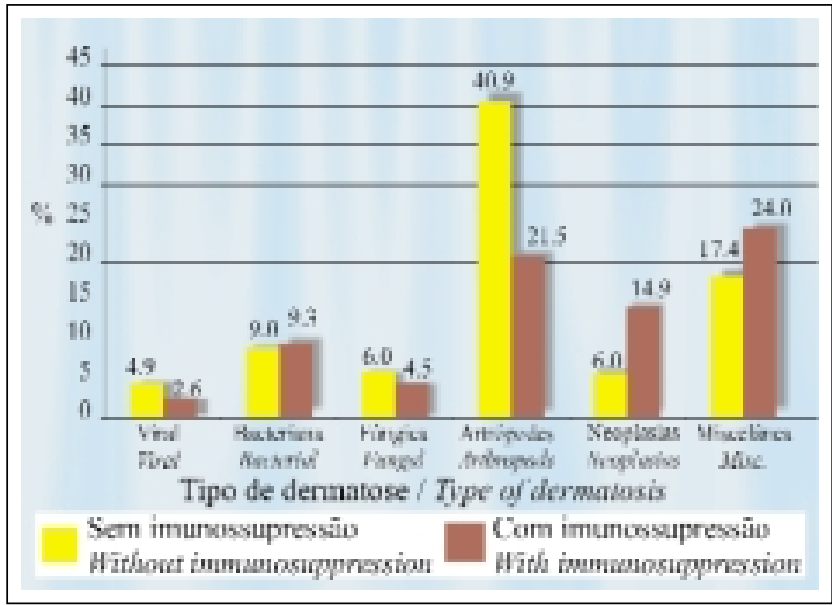

eczema, psoriasis, xeroderma, erythroderma, of photoallergic contact dermatitis, granuloma annulare, lupus erythematosus and vitiligo), fungal and viral, which represented 38\%, 34.4\% and $15.1 \%$ of the sample, respectively.

The eight most frequent diagnoses (74.6\% of all dermatoses), were: dermatophytosis, seborrheic dermatitis, papular pruritic eruption (PPE of HIV), common wart, candidiasis mucocutaneous, versicolor pityriasis, acquired ichthyosis and herpes simplex.

Forty two patients presented 49 lesions in the mucous membranes at clinical inspection (28.4\% of the sample), of which 20 were oral lesions (11 cases of candidiasis, six of oral pilar leukoplasia, one herpes simplex, one herpes zoster and one lymphoma without histological classification), three anal (two cases of condyloma acuminatum and one case of herpes simplex) and 26 genital (eight cases of condyloma acuminatum, seven cases of herpes simplex, four of molluscum contagiosum, three of bacterial balanoposthitis, two cases of balanoposthitis candidiasis, one of bowenoid papulosis and one of vitiligo).

The frequency of the dermatoses, as well as the $\mathrm{CD}_{4}+\mathrm{T}$ lymphocytes counts and viral loads for each respective diagnosis are shown in table 1.

A graphical representation of the extension of skin involved by the dermatoses in the patients with and without marked immunosuppression can be seen in graphic 2.

The mean value $\mathrm{CD}_{4}+\mathrm{T}$ lymphocytes, in absolute numbers (cells $/ \mathrm{mm}^{3}$ ) was of 383.15, and 1,147.00 for the $C D_{8}+T$ lymphocytes with a mean ratio of $C D 4 / C D 8=0.33$ and viral load of 109,114.05 cps/ml.

The predominant values of $\mathrm{CD}_{4}+T$ lymphocytes were above 200 cells $/ \mathrm{mm}^{3}$ (73.8\% of the sample), The most frequent viral load values ranged from undetectable to $50,000 \mathrm{cps} / \mathrm{ml}$ 
Tabela 2: Freqüências absolutas e percentuais das dermatoses segundo categoria de dermatoses e grau de imunidade dos pacientes. Significância do teste para comparação de freqüências.

Table 2: Absolute frequencies and percentages of the dermatoses, according to classification of the dermatoses and degree of immunity among the patients. Test significance to compare frequencies.

\begin{tabular}{|c|c|c|c|c|c|c|c|c|}
\hline \multirow{3}{*}{$\begin{array}{l}\text { Tipo de Dermatose } \\
\text { Type Of Dermatosis }\end{array}$} & \multicolumn{4}{|c|}{ Grupo / Group } & \multirow{2}{*}{\multicolumn{2}{|c|}{$\begin{array}{c}\text { Total de dermatoses } \\
\text { por grupo } \\
\text { Total dermatoses } \\
\text { per group }\end{array}$}} & \multirow{2}{*}{\multicolumn{2}{|c|}{$\begin{array}{c}\text { Teste Qui-quadrado } \\
\text { Chi-square test }\end{array}$}} \\
\hline & \multicolumn{2}{|c|}{$\begin{array}{l}\text { Sem imunossupressão } \\
\text { acentuada / With marked } \\
\text { immunosuppression } \\
\end{array}$} & \multicolumn{2}{|c|}{$\begin{array}{c}\text { Com Imunossupressão } \\
\text { Acentuada / Without } \\
\text { marked immunosuppression }\end{array}$} & & & & \\
\hline & Freq. & $\%$ & Freq. & $\%$ & Freq. & $\%$ & $\mathrm{G}^{2}$ & $\mathrm{p}$ \\
\hline Miscelânea / Miscellaneous & 83 & 36.2 & 53 & 41.1 & 136 & 38 & 0.50 & 0.9920 \\
\hline Fúngica / Fungal & 82 & 35.8 & 41 & 31.8 & 123 & 34.4 & 0.39 & 0.5304 \\
\hline Viral / Viral & 31 & 13.5 & 23 & 17.8 & 54 & 15.1 & 0.99 & 0.3209 \\
\hline Bacteriana / Bacterial & 21 & 9.2 & 3 & 2.3 & 24 & 6.7 & 6.81 & 0.0091 \\
\hline Artrópodes / Arthropods & 11 & 4.8 & 1 & 0.8 & 12 & 3.4 & 4.99 & 0.0255 \\
\hline Neoplasias / Neoplasias & 1 & 0.4 & 8 & 6.2 & 9 & 2.5 & 10.95 & 0.0009 \\
\hline Total & 229 & 100 & 129 & 100 & 358 & 100 & 24.62 & 0.0002 \\
\hline
\end{tabular}

valores de carga viral mais freqüentes estavam em intervalo entre indetectável e 50.000 cópias $/ \mathrm{ml}$ ( $71,5 \%$ da amostra).

Comparando-se os dados de carga viral com as quantificações de linfócitos $\mathrm{T}_{\mathrm{CD}_{4}}$, verifica-se que seus valores são inversamente proporcionais, havendo uma correlação linear, estatisticamente significante, entre o logaritmo das duas variáveis.

Comparando-se as freqüências percentuais das dermatoses, em grupos distintos de imunossupressão, observou-se diferença, estatisticamente significante $(\mathrm{p}=0.0002)$, conforme tabela 2.

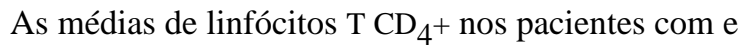
sem imunossupressão acentuada diferem, de modo estatisticamente significante, em todos os grupos de número de dermatoses (Tabela 3).

\section{(71.5\% of the sample).}

Comparing the viral load data with the values for the $\mathrm{CD}_{4}+\mathrm{T}$ lymphocytes, ascertain whether the values are inversely proportional and with a linear relationship, between the logarithms of the two variables.

Comparison of the percentage frequencies of the dermatoses with the distinct groups of immunosuppression, showed a statistically significant difference ( $p=0.0002)$, see table 2 .

There was a statistically significant difference in the mean values of $\mathrm{CD}_{4}+$ Tlymphocytes in patients either with and without marked immunosuppression in all the groups according to number of dermatoses. (see Table 3).

The mean values and standard deviations for the $\mathrm{CD}_{4}+$ $T$ lymphocytes and viral load for the diverse dermatoses are shown in table 4.

Tabela 3: Distribuição das médias e desvios padrões de linfócitos $\mathrm{CD}_{4}+$ em 172 pacientes, atendidos no HGT (Natal/RN) no período de setembro/1999 a fevereiro/2000, conforme suas categorias de imunidade e número de dermatoses apresentadas. Teste de significância T-student.

Table 3: Distribution of the mean and standard deviations of the $\mathrm{CD}_{4}+$ Iymphocytes in 172 patients attended at the HGT (Natal/RN) from September 1999 to February 2000, according to their category of immunity and number of dermatoses presented. Student's T test.

\begin{tabular}{|c|c|c|c|c|c|c|c|c|}
\hline \multirow[t]{2}{*}{$\begin{array}{l}\text { Número de dermatoses } \\
\text { por paciente } \\
\text { Type Of Dermatosis }\end{array}$} & \multicolumn{3}{|c|}{$\begin{array}{l}\text { Pacientes sem imunossupressão } \\
\text { acentuada / Patients with marked } \\
\text { immunosuppression }\end{array}$} & \multicolumn{3}{|c|}{$\begin{array}{l}\text { Pacientes com imunossupressão } \\
\text { acentuada / Patients without marked } \\
\text { immunosuppression }\end{array}$} & \multirow[t]{2}{*}{$\mathrm{t}(\mathrm{gl})$} & \multirow[t]{2}{*}{$\mathrm{p}$} \\
\hline & N. & $\begin{array}{l}\text { Média } \\
\text { Mean }\end{array}$ & $\begin{array}{c}\text { Desvio padrão } \\
\text { S.D. }\end{array}$ & N. & $\begin{array}{l}\text { Média } \\
\text { Mean }\end{array}$ & $\begin{array}{c}\text { Desvio padrão } \\
\text { S.D. }\end{array}$ & & \\
\hline 1 & 35 & 464.9 & 229.2 & 12 & 187.5 & 108.7 & $4.02(45)$ & 0.000 \\
\hline 2 & 57 & 504.1 & 260.5 & 23 & 139.3 & 121.6 & $6.42(78)$ & 0.000 \\
\hline 3 & 20 & 521 & 329 & 10 & 147.7 & 183.9 & $3.32(28)$ & 0.025 \\
\hline 4 & 6 & 379.3 & 132.8 & 9 & 140.7 & 118.1 & $3.65(13)$ & 0.029 \\
\hline Total & 118 & 489 & 259.1 & 54 & 151.8 & 129.7 & $9.05(170)$ & 0.000 \\
\hline
\end{tabular}


Gráfico 3: Distribuição da carga viral (cps/ml), em logaritmos, conforme o número de dermatoses apresentadas por paciente em

172 indivíduos avaliados no HGT (Natal/RN) no período de setembro/1999 a fevereiro/2000.

Graphic 3: Distribution of the viral load (cps/ml) in logarithms per group of dermatoses, in 172 patients attended at the HGT in Natal/RN, from September 1999 to February 2000.

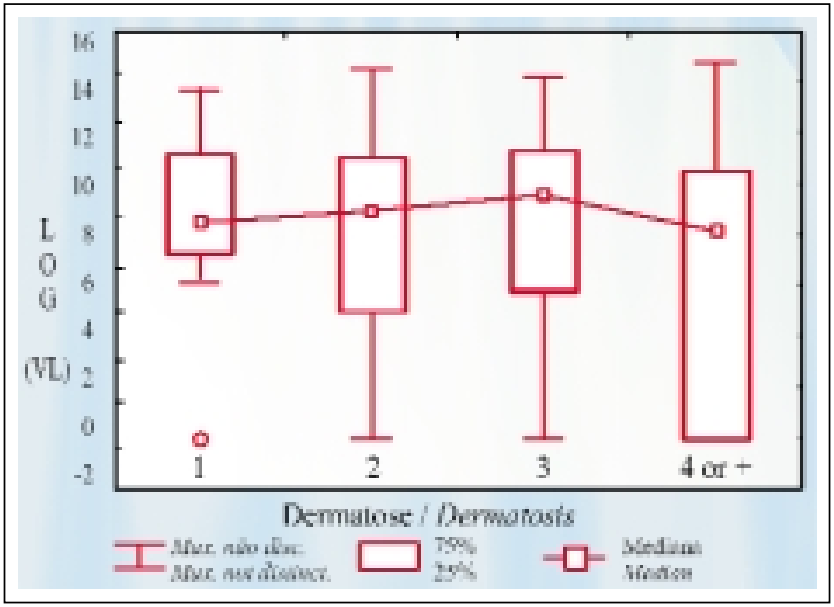

As médias e desvios padrões de linfócitos $\mathrm{T} \mathrm{CD}_{4}+\mathrm{e}$ de CV para as diversas dermatoses estão na Tabela 4.

O gráfico 3 demonstra a acentuada variabilidade dos valores de $\mathrm{CV}$, mesmo após transformados em logaritmos.

Correspondendo a $81,4 \%$ da amostra, 140 indivíduos faziam uso de antiretrovirais, no momento da primeira consulta dermatológica. Desses pacientes, $66(47,2 \%)$ usavam inibidor de protease em associação com outras drogas antiretrovirais, e $74(52,8 \%)$ utilizavam associações de antiretrovirais que não incluíam inibidores da protease à época da consulta dermatológica.

As associações mais comuns de medicamentos antiretrovirais foram dois nucleosídeos inibidores da transcriptase reversa (ITRN) e dois ITRNs associados a um inibidor da protease.

A representação gráfica da distribuição percentual de pacientes quanto ao uso ou não de medicamentos antiretrovirais e ao número de dermatoses encontra-se no Gráfico 4.

$\mathrm{O}$ resultado do teste T-student, comparando percentual médio de pele atingida pelas dermatoses entre os pacientes que usavam ou não tratamento antiretroviral, revelou não haver diferença estatisticamente significante.

\section{DISCUSSÃO}

$\mathrm{Na}$ epidemiologia descritiva há categorias básicas, como distribuições temporal, espacial e de atributos pessoais, visando identificar o padrão geral de ocorrência e os grupos sob risco de adoecer. Sendo a Aids uma doença emergente, estudos descritivos são necessários para indicar as características epidemiológicas na coletividade. ${ }^{22}$

O estudo descritivo de série de casos não permite, entretanto, o controle de bias ou vieses, de modo que se pode confundir associação de eventos com relação causa/efeito
Gráfico 4: Distribuição percentual dos 172 pacientes atendidos no HGT (Natal/RN) no período de setembro/1999 a fevereiro/2000, quanto ao número de dermatoses e uso ou não de ARV.

Graphic 4: Distribution of the 172 patients attended at the HGT (Natal/RN) from September 1999 to February 2000, according to the number of dermatoses and use or nonuse of antiretrovirals (ARV).

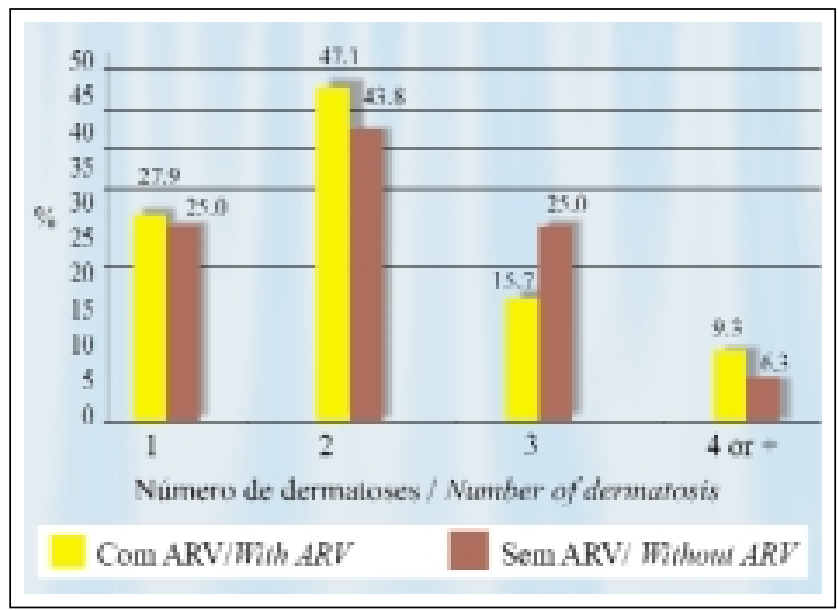

Graphic 3 shows the marked variability in the values of the viral load, even after transformation into logarithms.

At the first dermatological consultation, 140 individuals corresponding to $81.4 \%$ of the sample, were using antiretroviral drugs. Of these patients, 66 (47.2\%) used protease inhibitors in association with other antiretroviral drugs and 74 (52.8\%) used antiretroviral associations that did not include protease inhibitors at the time of the dermatological consultation.

The most common associations of antiretroviral medicines were two nucleoside inhibitors of the reverse transcriptase (NTRI) and two NTRI associated to a protease inhibitor.

Graphic 4 is a graphical representation of the patients' percentage distribution regarding the use or nonuse of antiretroviral medicines and the number of dermatoses presented.

The result of applying the Student's T test to compare the mean percentage of skin involved by the dermatoses between the patients receiving or not receiving antiretroviral treatment, revealed that there was no statistically significant difference.

\section{DISCUSSION}

In descriptive epidemiology there are basic categories, such as distributions according to time, region and personal attributes in order to identify a general pattern of occurrence in the at-risk groups. Since Aids is an emerging disease, descriptive studies are necessary to indicate the epidemic characteristics in the various populations. ${ }^{22}$

Descriptive study of case series does not allow, however, the control of bias, which can confuse the association of events with a causeleffect relationship between the 
entre os mesmos eventos ou achados estatísticos.

Bias são erros sistemáticos, portanto, não decorrentes do acaso, que determinam estimativas incorretas de associações entre exposições e risco de adoecer.

Eles podem ser minimizados, em estudos analíticos no momento do desenho do estudo, por meio de: randomização da amostra (dividir a amostra em grupos a serem comparados com características idênticas); restrição (não incluir na amostra fatores sabidamente confundidores da associação causa/efeito) e pareamento (relacionar grupos com graus crescentes de potencial confundidor, ou seja, os casos e controles a serem comparados possuem fatores de confusão distribuídos de maneira idêntica).

Apenas 17,7\% dos pacientes com doença cutânea não foram incluídos, por não possuírem quantificação dos marcadores imunitários, sendo estas as suas características: 26 homens e 11 mulheres, com idade média de 35,3 anos, apresentando 71 dermatoses (média de 1,9 dermatoses/paciente). Esse percentual baixo não compromete a fidedignidade das frequiências de dermatoses obtidas no trabalho.

Optou-se, pela obtenção da extensão percentual de pele atingida pelas dermatoses, tomando-se como assertivo o comentário de Smith et al., ${ }^{13}$ que descreve relação positiva entre gravidade das dermatoses e progressão da imunossupressão.

Todas as informações obtidas por relato verbal dos pacientes (estado civil, escolaridade, comportamento sexual, procedência, área de moradia, profissão à época da primeira sorologia anti-HIV positiva, via provável de contaminação, motivo da procura de serviço especializado em atendimento em Aids) foram sujeitas a bias de informação recordatório.

As características epidemiológicas da amostra corresponderam às descrições em boletins epidemiológicos no Brasil, principalmente em relação às características de idade, sexo, via de infecção e área de moradia, incluindo a maior frequiência de bissexuais infectados, em relação ao número de homossexuais, no estudo, tendência já detectada no Brasil. ${ }^{24,25}$

As categorizações da carga viral e do número de linfócitos $\mathrm{T} \mathrm{CD}_{4}+$ espelharam-se em guias de terapêutica de indivíduos soropositivos ao vírus HIV $^{25,27}$ e de publicações que avaliaram a presença de dermatoses em níveis variados de medidas de linfócitos $\mathrm{T} \mathrm{CD}_{4}+{ }^{10,12,13,17,18,28-30}$

Encontrou-se alta variabilidade individual de valores de carga viral, dificultando sua interpretação como preditor de imunocompetência, já que seu valor como prognóstico de morbimortalidade e controle de eficácia terapêutica é largamente aceito. . $^{3,7,8,23}$

Portanto, valores de desvios padrões maiores do que as médias de cargas virais foram encontrados em todos os grupos de dermatoses (Tabela 4).

Os motivos mais freqüentes de procura de serviço especializado em Aids apontam para uma baixa proporção same events or statistical findings.

Bias is a systematic error - therefore, it does not arise due to chance - which determines incorrect estimates of associations between exposure and the risk of developing a certain disease.

Bias in analytical studies can be minimized during the planning stage by means of: randomizing the sample (by dividing the sample into groups with identical characteristics for comparison); exclusion (eliminating factors in the sample that are known to confuse the causeleffect relationships) and pairing (relate groups with an increasing degrees of the confounding parameter, or that is, the cases and controls to be compared have confounding factors distributed in an identical manner).

Only $17.7 \%$ of the patients with cutaneous disease were not included, as there was no record of the quantification of immune markers, their characteristics were: 26 men and 11 women, with a mean age of 35.3 years, presenting 71 dermatoses (mean 1.9 dermatoses/patient). This low percentage did not compromise the reliability of the results for the frequencies of dermatoses found in this work.

It was decided to obtain the percentage of skin involved by the dermatoses, based on the findings of Smith et al., ${ }^{13}$ who describe a close relationship between the severity of the dermatoses and progression of the immunosuppression.

All the information obtained verbally from the patients (marital status, educational level, sexual behavior, origin, home area, profession at the time of the first positive anti-HIV serology, probable means of contamination and motive for seeking specialized Aids service) was subject to bias in remembered information.

The epidemiological characteristics of the sample corresponded to the descriptions of epidemic bulletins in Brazil, mainly in relation to the characteristics of age, sex, means of infection and home area, including a higher frequency of infected bisexuals, in relation to the number of homosexuals in the study. This trend had already been detected in Brazil. ${ }^{24,25}$

The viral load categories and number of $\mathrm{CD}_{4}+\mathrm{T}$ lymphocytes reflected the guides for therapeutics of HIV seropositive individuals ${ }^{25,27}$ and the publications that evaluated presence of dermatoses in varied levels of $\mathrm{CD}_{4}+\mathrm{T}$ lymphocytes. ${ }^{10,12,13,17,18,28-30}$

A high individual variability was found in the viral load values, hindering their interpretation as a predictor of immunocompetence, although their value as a prognostic of morbimortality and control of therapeutic effectiveness is widely accepted. . $^{3,7,8,23}$

Therefore, higher values of standard deviation than the means for viral loads were found in all the groups of dermatoses (Table 4).

The most frequent reasons for seeking specialized attendance at the Aids service point to a low proportion of cases diagnosed by health workers; cohabitation, under 
Tabela 4: Distribuição das médias de linfócitos $T \mathrm{CD}_{4}+$ (células $/ \mathrm{mm}^{3}$ ) e carga viral $(\mathrm{cps} / \mathrm{ml})$ por grupo de dermatoses, em 172 pacientes atendidos no HGT em Natal/RN, no período de setembro/1999 a fevereiro/2000.

Table 4: Mean values for the $\mathrm{CD}_{4}+$ T lymphocytes (cells/mm $)$ and viral load $(\mathrm{cps} / \mathrm{ml})$ per group of dermatoses, in 172 patients attended at the HGT in Natal/RN, from September 1999 to February 2000.

\begin{tabular}{|c|c|c|c|c|c|}
\hline \multirow{3}{*}{$\begin{array}{l}\text { Tipo de } \\
\text { dermatose } \\
\text { Type Of } \\
\text { Dermatosis }\end{array}$} & \multirow{3}{*}{$\begin{array}{l}\text { Número de } \\
\text { dermatoses } \\
\text { Number of } \\
\text { dermatoses }\end{array}$} & \multicolumn{2}{|c|}{$\begin{array}{l}\text { Linfócitos T CD4+ } \\
\text { CD4+ T Lymphocytes }\end{array}$} & \multicolumn{2}{|c|}{$\begin{array}{c}\text { Carga viral } \\
\text { Viral load }\end{array}$} \\
\hline & & Média & Desvio padrão & Média & Desvio padrão \\
\hline & & Mean & S.D. & Média & S.D. \\
\hline Miscellaneous & 136 & 329.1 & 252.5 & $128,308.7$ & $380,256.6$ \\
\hline Fungal & 123 & 376 & 276.7 & $156,657.3$ & $427,053.6$ \\
\hline Viral & 54 & 379.5 & 269.7 & $75,080.9$ & $223,072.9$ \\
\hline Bacterial & 24 & 527.4 & 372.1 & $133,243.7$ & $528,185.3$ \\
\hline Arthropods & 12 & 529.3 & 396.4 & 202,907 & $569,020.6$ \\
\hline Neoplasias & 9 & 195.2 & 109.9 & $26,854.4$ & $39,089.2$ \\
\hline
\end{tabular}

de casos diagnosticados por equipe de saúde; convivência, sob risco de contaminação, entre parceiros conhecidos; e pouco conhecimento da população infectada sobre os sintomas ou, mesmo, desconhecimento dos casos de soropositividade assintomática.

$\mathrm{O}$ achado de maior freqüência de indivíduos infectados com grau de escolaridade entre primeiro grau $(57 \%$ dos casos) e segundo grau (23,3\%), em detrimento de casos de analfabetos $(10,5 \%)$, é digno de nota, estimando-se maior e melhor assimilação das informações sobre Aids por indivíduos de maior grau de escolaridade, embora também seja achado concordante com a literatura nacional. ${ }^{26}$

Estudos que extrapolem as descrições e análises comportamentais serão necessários para compreender esse achado, podendo discriminar suas causas no contexto da vulnerabilidade social brasileira. ${ }^{31}$

O encontro de maior número de dermatoses eritêmato-descamantes, incluídas no grupo miscelânea, seguido das dermatoses de etiologia fúngica e viral coincidiu com relatos mundiais e nacionais, em que essas três categorias de dermatoses incluem as doenças da pele mais freqüentes em infectados pelo retrovírus. ${ }^{2,13,17,32,33}$

Não se conseguiu, porém, subcategorizar o grupo miscelânea em classificação aceita cientificamente, pois reúne doenças de etiologias variadas e algumas sem etiologia definida.

Há diferenças na prevalência de dermatoses entre homens e mulheres infectados pelo retrovírus, ${ }^{30,35}$ e essas apresentam menor freqüência de sarcoma de Kaposi (três casos em homens e nenhum em mulheres) e leucoplasia pilosa oral (cinco casos em homens e um caso em mulher) neste estudo.

Embora haja relato de maior frequência de $T$. rubrum como dermatófito mais freqüente entre infectados pelo vírus HIV, ${ }^{17} \mathrm{o}$ encontro de maior frequiência de outros dermatófitos, na população geral, é relatado na literatura nacional, correspondendo, muitas vezes, às condições ambientais das regiões estudadas. ${ }^{36-38}$

Observou-se que a espécie T. mentagrophytis esteve risk of contamination, between known partners, and scant knowledge of the infected population regarding the symptoms or even total ignorance of the possibility of asymptomatic seropositive cases.

The finding of a greater frequency of infected individuals with education level between first grade $(57 \%$ of cases) and second grade (23.3\%), compared to illiterate patients (10.5\%), is worthy of note, since one would expect a better assimilation of information regarding Aids among individuals with a higher educational level, although this finding is corroborated by the national literature. ${ }^{26}$

Further studies that extrapolate the behavioral descriptions and analyses will be necessary to clarify this finding in terms of identifying its causes in the context of the Brazilian social vulnerability. ${ }^{31}$

The finding of a larger number of erythematous squamous dermatoses, included in the miscellaneous group, followed by dermatoses of fungal and viral etiology coincided with world and national reports, in that these three categories of dermatoses include the most frequent skin

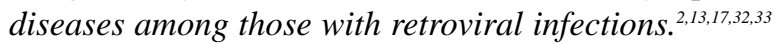

It was not possible, however, to classify the miscellaneous group into scientifically accepted subcategories, since it includes pathologies with varied etiologies and others in which the etiology has yet to be defined.

There were differences in the prevalence of dermatoses according to gender in subjects infected by a retrovirus, ${ }^{30,35}$ and women presented a lower frequency of Kaposi's sarcoma (three cases involving men and none in women) and oral pilar leukoplasia (five cases in men and one case involving a woman) in this study.

Although it has been reported that $\mathrm{T}$. rubrum is the most frequent dermatophyte among those infected with $H I V,{ }^{17}$ the finding of a greater frequency of other dermatophytes in the general population has been reported in the national literature, often corresponding to the environmental conditions of the regions studied. ${ }^{36-38}$

It was observed that $\mathrm{T}$. mentagrophytis was present in most of the dermatophytoses (13 records), against only 
presente na maioria das dermatofitoses (13 registros), em detrimento de oito casos de T. rubrum. Quanto às leveduras, houve crescimento de colônias em nove cultivos.

Estudos descritivos, abrangendo populações imunocompetentes e imunossuprimidas, serão necessários ao melhor esclarecimento desses achados no Rio Grande do Norte.

A alta frequiência de isolamento de $S$. aureus na pele acometida por dermatoses bacterianas em infectados pelo vírus HIV é concordante com a literatura mundial, ${ }^{17,39,40}$ sendo descritos por Onorato et ll $^{41}$ os fatores de risco para aquisição de cepas meticilinarresistentes em indivíduos anti-HIV positivos: hospitalização prévia, exposição a antibióticos de largo espectro, presença de acesso venoso central, e doenças dermatológicas.

Foram detectados 15 pacientes, dos quais se isolou $S$. aureus, todos os casos resistentes à penicilina $\mathrm{G}$ e/ou ampicilina, sendo duas colônias também resistentes à oxacilina, uma colônia sem teste para oxacilina e 12 colônias sensíveis à oxacilina. Isolaram-se quatro colônias de $S$. epidermidis, todos sensíveis à oxacilina e resistentes à penicilina $\mathrm{G}$ e ampicilina.

Os resultados das biópsias efetuadas nos casos, clinicamente relatadas como EPP do HIV, evidenciaram padrões histológicos descritos na literatura, como infiltrado inflamatório linfocitário predominante, de localização perianexial e/ou perivascular superficial e/ou profundo, e presença de eosinófilos.

Há relato, para casos de dermatoses inflamatórias, de achado freqüente de hiperqueratose e/ou acantose, e raros achados de granulomas, ${ }^{13}$ embora se tenha obtido um registo de granuloma anular perfurante.

Não se conseguiu informação fidedigna do tempo de uso de medicamentos antiretrovirais, já que muitos pacientes tiveram necessidade de uso de mais de um esquema terapêutico ou não utilizavam corretamente os medicamentos descritos em seus prontuários.

Como se espera evolução nas pesquisas no que se refere a essa pandemia, novos medicamentos antiretrovirais virão, de modo que estudos sobre o comportamento de doenças oportunistas e co-participantes, em especial as dermatoses, por serem as mais freqüentes nesse grupo de doentes, serão importantes para comparar eficácia e valor preditivo de competência imunológica em usuários de novos antiretrovirais.

\section{CONCLUSÕES}

As características epidemiológicas dos pacientes infectados pelo vírus HIV no Rio Grande do Norte não diferem das características dos pacientes nos demais estados brasileiros.

As dermatoses mais freqüentes: eritêmato-descamantes (incluídas no grupo miscelânea), fúngicas e virais coincidem com as descritas em artigos científicos.

A amostra de pacientes, com média de número de linfócitos $\mathrm{T} \mathrm{CD}_{4}+$ acima de 200 céls $/ \mathrm{mm}^{3}$ e valores de carga eight cases of T. rubrum. As for the yeasts, there was growth of colonies in nine cultures.

Descriptive studies, involving immunocompetent and immunosuppressed populations, are necessary to better explain these findings in Rio Grande do Norte.

The high frequency in which $\mathrm{S}$. aureus was isolated in the skin involved by bacterial dermatoses among HIV patients is concordant with world literature ${ }^{17,39,40}$ and it has been described by Onorato et al. ${ }^{41}$ The risk factors for acquisition of methicillin-resistant strains in anti-HIV positive individuals are: prior hospitalization, exposure to broad spectrum antibiotics, central venous catheterization and dermatological diseases.

Fifteen patients resistant to penicillin $G$ and/or ampicillin were detected, of which $\mathrm{S}$. aureus was isolated in all cases. Of these, two colonies were also resistant to oxacillin, one colony was not tested for oxacillin and 12 colonies were sensitive to oxacillin. Four colonies of $\mathrm{S}$. epidermidis were isolated and all the colonies were sensitive to oxacillin, but resistant to penicillin $G$ and ampicillin.

The results of the biopsies performed in those cases clinically reported as PPE of HIV, revealed histological patterns described in the literature as predominantly lymphocytic inflammatory infiltrate, with a periannexal and/or superficial and/or profound perivascular location, together with the presence of eosinophiles.

Among cases of inflammatory dermatoses, there are reports of frequent hyperkeratose and/or acanthotic findings and rare granulomas, ${ }^{13}$ although there was only one case of perforating granuloma annulare.

No reliable information was available regarding duration of the antiretroviral medication use, since many patients had required the use of more than one therapeutic regimen and/or had not used the medicines correctly as prescribed in their records.

Since progress is to be expected in the research into this pandemic, new antiretroviral medicines will be developed, such that studies regarding the behavior of opportunist and co-participating diseases (especially the dermatoses, as they are most frequent in this group of patients) will be important to compare the effectiveness and predictive value of immunological competence among users of the latest antiretroviral drugs.

\section{CONCLUSIONS}

The epidemiologic characteristics of HIV-infected patients in Rio Grande do Norte did not differ considerably from the characteristics of their counterparts in other Brazilian states.

The most frequent dermatoses: erythematous squamous (included in the miscellaneous group), fungal and viral, correspond to those described in scientific articles.

The sample of patients with a mean count of $\mathrm{CD}_{4}+\mathrm{T}$ lymphocytes above 200 cells $/ \mathrm{mm}^{3}$ and viral load values lower 
viral menores do que $50 \mathrm{mil}$ cópias $/ \mathrm{ml}$, em sua maioria em uso de antiretroviral, pode ter influenciado positivamente o achado de freqüências semelhantes de dermatoses por paciente entre usuários e não usuários de ARV.

A variabilidade individual dos marcadores de imunossupressão, principalmente da carga viral, seja em grupos de imunossupressão distintos, seja em usuários e não usuários de antiretroviral pode ter interferido negativamente na avaliação de gravidade das dermatoses.

A grande quantidade de fatores influenciando o estado imunitário dos pacientes com retrovirose em tratamento dificulta a análise dos riscos sobre o agravo, introduzindo bias de confusão difíceis de serem controlados, mesmo em estudos analíticos.

\section{REFERÊNCIAS / REFERENCES}

1. Matis W, Triana A, Shapiro R et al. Dermatologic findings associated with Human Immunodeficiency Virus infection. Journal of the American Academy of Dermatology. 1987;17(5):746-51.

2. Oliveira MM, Da Veiga RG, Sereno AB et al. Acquired Immune Deficiency Syndrome:cutaneous lesions. Anais Brasileiros de Dermatologia. 1988;63(2):63-6.

3. Epstein FH et al. Mechanisms of disease : the immunopathogenesis of Human Immunodeficiency Virus infection. The New England Journal of Medicine. 1993;328(5):327-35.

4. Bartlett JG Medical management of HIV infection. Glenview: Physicians e Scientists Publishing Co., Inc. 1996:381.

5. Brito AM A Epidemia de Aids em Pernambuco: sobrevida dos doentes no período de 1983 a 1995. Recife, 1997. 115p. Dissertação (Mestrado em Medicina Tropical)-Universidade Federal de Pernambuco, 1997.

6. Rico JM., Myers CSA, Sanchez MR. Guidelines of care for dermatologic conditions in patients infected with HIV. Journal of the American Academy of Dermatology 1997; 37(3):450-72.

7. Rachid M., Schechter M. Manual de HIV/Aids. $3^{\text {rd }}$ ed. Rio de Janeiro: Revinter, 1998:181p.

8. Sampaio SAP, Rivitti EA. Dermatologia. $1^{\text {st }}$ ed. São Paulo: Artes Médicas, 1998:737-52.

9. Valle SL Dermatologic findings related to Human Immunodeficiency Virus infection in high-risk individuals. Journal of the American Academy of Dermatology, 1987;17(6):951-61.

10. Fleischer Junior AB, Gallagher PN, Van Der Horst C. Mucocutaneous abnormalities predicted by lymphocyte counts in patients infected with the Human Immunodeficiency Virus. Southern Medical Journal 1992; 85(7): 687-90.

11. Raza A, Berger T. Comon superficial fungal infections in patients with Aids. Clinical Infectious Diseases, 1996;22:128-32 Suppl.2.

12. Reynaud-Mendel B, Janier M, Gerbaka J et al. Dermatologic findings in HIV-1 infected patients: a prospective study with emphasis on $\mathrm{CD}_{4}+$ cell count. Dermatology. 1996;192:325-28.

13. Smith KJ, Skelton HG, Yeager J et al. Cutaneous findings in than 50,000 cps/ml, most of which undergoing antiretroviral therapy, may have positively influenced the findings of similar frequencies of dermatoses among those patients that were or were not using antiretroviral medication.

The variability in the individual markers of immunosuppression and principally in the viral load - whether in the groups with distinct immunosuppression, or users and nonusers of antiretroviral agents may have interfered negatively in the evaluation of the seriousness of the dermatoses.

The numerous factors influencing the immune state of patients under treatment for retrovirus hindered the analysis offence of aggravating risks by introducing a confounding bias which was difficult to control even in an analytical study.

HIV-1-positive patients: a 42-month prospective study. Journal of the American Academy of Dermatology. 1994; 31(5):746-54.

14. Dover JS, Johnson RA. Cutaneous manifestations of Human Immunodeficiency Virus infection, part I. Archives of Dermatology. 1991; 127(1):1383-91.

15. Ramos H. Erupção papular prurítica associada ao Vírus da Imunodeficiência Humana: etiopatogênese avaliada por análise clínica, imuno-histoquímica e ultra-estrutural. 1998. 148p. Dissertação (Doutorado em Medicina Tropical) - Faculdade de Medicina, Universidade de São Paulo, 1998.

16. Brasil. Ministério da Saúde. Secretaria de Políticas de Saúde. Coordenação Nacional de DST e Aids. Manual de Contagem de Linfócitos $\mathrm{T} \mathrm{CD}_{4}+$. Brasília, 1998. 110 p.

17. Johnson RA. Human Immunodeficiency Virus disease in the era of HAART: a reevaluation of the cutaneous manifestations. Current Clinical Tropical Infectious Disease. 1999; 19: 252-86.

18. Zalla MJ, Su WP, Fransway AF. Dermatologic manifestations of Human Immunodeficiency Virus infection. Mayo Clinic Proc. 1992; 67: 1089-1108.

19. Ray MC, Gately III LE. Dermatologic manifestations of HIV infection and Aids. Infectious Disease Clinics of North America. 1994; 8(3):583-605.

20. Costa SM, Tostes, ROG. Queimaduras. In: Fonseca FP, Rocha PRS. Cirurgia ambulatorial. 2nd ed. Rio de Janeiro: Guanagara Koogan, 1987:136-145.

21. Brasil. Ministério da Saúde. Secretaria de Políticas de Saúde. Coordenação Nacional de DST e Aids. Manual de Contagem de Linfócitos $\mathrm{T} \mathrm{CD}_{4}+$. Brasília, 1998. 110 p.

22. Informe Epidemiológico do SUS. O desafio das doenças emergentes e a revalorização da epidemiologia descritiva. 1999;8(1):7-15.

23. Hughes MD, Johnson VA, Hirsch MS et al. Monitoring plasma HIV-1 levels in addition to $\mathrm{CD}_{4}+$ lymphocyte count improves assesment of antiretroviral therapeutic response. Annals of Internal Medicine. 1997; 126(12):929-38.

24. Boletim Epidemiológico, Aids. Brasília: Ministério da Saúde, v.13, n.1, dez.1999/jun. 2000. 56p. 
25. Boletim Epidemiológico, Aids. Brasília: Ministério da Saúde, v.1, n.1, dez. 1998/fev. 1999. 55p.

26. Brasil. Ministério da Saúde. Secretaria de Políticas de Saúde. Coordenação Nacional de DST e Aids. Controle de infecções e a prática odontológica em tempos de Aids: manual de condutas. Brasília, 2000. 118p.

27. Carpenter CCJ, Cooper DA, Fischl MA et al. Antiretroviral therapy in adults: updated recommendations of the International Aids Society-USA Panel. JAMA. 2000; 283(3): 381-90.

28. Fisher BK, Warner LC Cutaneous manifestations of the Acquired Immunodeficiency Syndrome: update 1987. International Journal of Dermatology. 1987; 26(10):615-30.

29. Stewart GJ. The cronology of HIV-induced disease. The Medical Journal of Australia. 1993;158(4):3-5.

30. Barton JC, Buchness MR. Nongenital Dermatologic Disease in HIV-infected women. Journal of the American Academy of Dermatology.1999; 40(6): 938-48.

31. Ayres JRCM. Aids, vulnerabilidade e prevenção. In: SEMINÁRIO DE SAÚDE REPRODUTIVA EM TEMPOS DE Aids, 2, 1997, Rio de Janeiro. Programa de estudos e pesquisa em gênero, sexualidade e saúde. Rio de Janeiro: Instituto de Medicina Social da Universidade do Estado do Rio de Janeiro, 1997. p.20-37. 32. Rosatelli JB, Machado AA, Roselino AM. Dermatoses among brazilian HIV - positive patients: correlation with the evolutionary phases of Aids. International Journal of Dermatology. 1997;36:729-34. 33. Chaisson R, Dyer J. Dermatologic complications. In: WORLD AIDSCONFERENCE, 12, 1998. <http://www.medscape.com/medscape/cno/1998/AIDS_HGG/Story.cfm?story_id=73> Acesso em 20 mar. 2000

34. Oliveira MM, Veiga RG, Sereno AB, Manela M, Jr. ACP. Acquired Immune Deficiency Syndrome: cutaneous lesions. Anais Brasileiros de Dermatologia 1988;63(2):63-66.
35. Husak R, Garbe C, Orfanos CE. Oral hairy leukoplasia in 71 HIV seropositive patients: clinical symptoms, relation to immunologic status, and prognostic significance. American Academy of Dermatology,1996;35(6):928-34.

36. Mattêde MGS. Etiologia das dermatofitoses em Vitória (ES). Anais Brasileiros de Dermatologia. 1986;61(4):82-177.

37. Gonçalves HMG. Dermatofitoses: principais agentes etiológicos encontrados em Fortaleza, Brasil. Anais Brasileiros de Dermatologia. 1989;64(1):7-25.

38. Marques SA. Micoses oportunísticas e de comportamento oportunista no Brasil. Anais Brasileiros de Dermatologia,1996;71(2):25-9 Supl.

39. Duvic, M. Human Immunodeficiency Virus and the skin: selected controversies, The Journal of Investigative Dermatology. 1995;105(1) Suppl.

40. Clay JC. Cutaneous signs of HIV infection. In: Textbook of Aids medicine. $2^{\text {nd }}$ ed. Baltimore: Williams \& Wilkins, 1999;31:499-520.

41. Onorato M, Borucki MJ, Gwen BBA et. al. Risk factors for colonization or infection due to methicillin-resistant Staphylococcus aureus in HIV-positive patients: A retrospective case-control study. Infection Control and Hospital Epidemiology. 1999;20(1)26-30.

ENDEREÇO PARA CORRESPONDÊNCIA: / MAILING ADDRESS: Fernando Cardoso

Av. Rui Barbosa, 1122 - BI. B - Apto. 802

Natal RN 59075-300

Tel/Fax: (84) 211-9643 / 211-3771

E-mail: fnetmail@digi.com.br 